\title{
電離指数計算による標準球ギャップ 火花電圧の変動要因の検討
}

\author{
学生員 高野 理 （工学院大） 正 員 錦織康男 （工学院大） \\ 正 員 村野 稔 （工学院大） 正 員 河野照哉 （工学院大）
}

Investigation of Factors Affecting Disruptive Discharge Voltages of Standard Sphere-gap by Calculation of Ionization Index Osamu Takano, Student Member, Yasuo Nishikori, Member, Minoru Murano, Member, Teruya Kouno, Member

(Kogakuin University)

キーワード : 球ギャップ, 火花電圧, 電離指数，インパルス電圧测定，電界計算

1.はじめに

最近の高電圧測定に関する国際規格（ＩＥＣ６０－2） の改訂にともない，インパルス電圧測定における測定誤差 の検討が従来にも増して重要な課題になっている。そこで, インパルス電圧測定の標準测定器である球ギャップの火花 電圧に，電界を通じて影響を及ぼす諸要因，例えば接地面 までの距離や柄の長さや太さなどの影響を定量的に推定す る研究を始めたので，現在までの結果を報告する。

火花電压がどの程度影響されるのかの評価は，球ギャッ プの中心軸上の電界を計算し，その電界における実效電離 係数を積分する手法（電離指数計算）を用いた。

2. 電界計算モデル

図 1 に電界計算モデルを示す。（a）は電界を求める際 に想定した電極形状を示し，図中の $\mathrm{d} ， \mathrm{H}_{1}, \mathrm{H}_{2}, \mathrm{~L}$ 変 数とする。（b）屾電荷重畳法における輪郭点と各仮想電 荷の配置状況を示す。

\section{3. 火花条牪式の検討}

電界計算の結果から，火花電圧を推定する方法は, Pedersen氏が空気中およびS F 8 ガス中における球ギャップ の火花電圧を計算した [1 ]，[2]，[3]と同様の手法を用 いた。式で表すと次の 3 式が考えられる。

$$
\begin{aligned}
& \ln \left(\alpha_{\mathrm{x}}\right)+\int_{0}^{\mathrm{x}} \alpha \mathrm{d} \mathrm{x}=\mathrm{g}_{\mathrm{i}}(\mathrm{x}) \\
& \frac{1}{2} \ln \left(\alpha_{\mathrm{x}}\right)+\int_{0}^{\mathrm{x}} \alpha \mathrm{d} \mathrm{x}=\mathrm{g}_{\mathrm{r}}(\mathrm{x}) \\
& \int_{0}^{\mathrm{x}} \alpha \mathrm{d} \mathrm{x}=\mathrm{g}_{\mathrm{e}}(\mathrm{x})
\end{aligned}
$$

これらはいずれも，電子なだれがストリーマに転換する 火花条件を定式化したもので，xは，電子なだれが出発す る点（積分の下限の0）からの中心軸上の距離， $\alpha$ は実效 電離係数である。式(1)は正イオン密度，(2)は正イオン 密度と電子密度との積（再結合密度），（３）は電子密度が, ある臨界值に達したときにストリーマに転換することを表
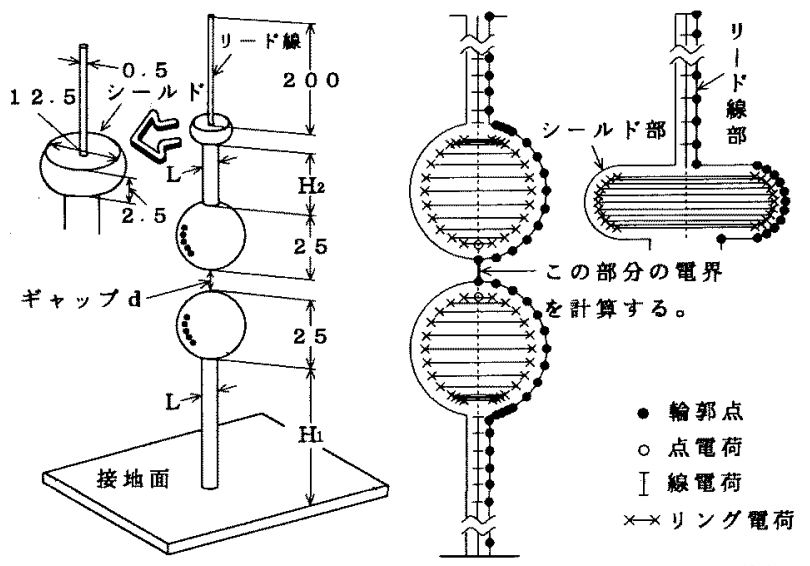

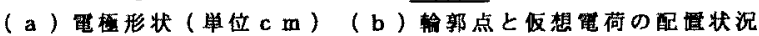

図 1 電界計算モデル

Fig.1. Calculation model for field strengths.

現している。右辺の $\mathrm{g}(\mathrm{x})$ の推定は, 平等電界と考えら れる電極での実験結果を用いる。図 1 において $H_{1}=100$ $\mathrm{cm}, \mathrm{H}_{2}=25 \mathrm{~cm}, \mathrm{~L}=5 \mathrm{~cm}$ とし, それそれの条件 で火花電圧の計算をすると表 1 の結果が得られる。

\begin{tabular}{|c|c|c|c|c|c|}
\hline \multirow{2}{*}{ 極性 } & \multirow{2}{*}{ ギャップ長 } & \multicolumn{4}{|c|}{ 火花電压 $[\mathrm{kV}]$} \\
\hline & & 式（1） & 式（2） & 式 (3) & IEC -52 \\
\hline \multirow{2}{*}{ 負 } & $2 \mathrm{~cm}$ & 59.12 & 59.14 & 59.20 & 59.00 \\
\hline & $10 \mathrm{~cm}$ & 248.00 & 247.33 & 246.60 & 244.00 \\
\hline & $2 \mathrm{~cm}$ & 59.12 & 59.14 & 59.20 & 59.00 \\
\hline & $10 \mathrm{~cm}$ & 254.97 & 255.49 & 255.95 & 254.00 \\
\hline
\end{tabular}

表 13 式で求められた火花電圧 $\left(\mathrm{H}_{1}=100 \mathrm{~cm}, \mathrm{H}_{2}=25 \mathrm{~cm}, \mathrm{~L}=5 \mathrm{~cm}\right)$ Table 1. Disruptive discharge voltages by three equations.

計算された火花電圧值にあまり差がないので, 最も簡明な ( 3 )式を用いることにした。

この報告は，火花電圧の絶対值を推定するのが目的では なく, 諸条件の影響を火花電圧の変化という面から, 検討 
するにはこの手法も意味があるのではないかと考えて採用 した。

\section{4. 計算結果}

図1においてギャップ長 $\mathrm{d}$ を $10 \mathrm{~cm}$ とし, 支持柄の長 さ $\mathrm{H}{ }_{1}$ を変化させたときの計算結果を図 2 に示す。

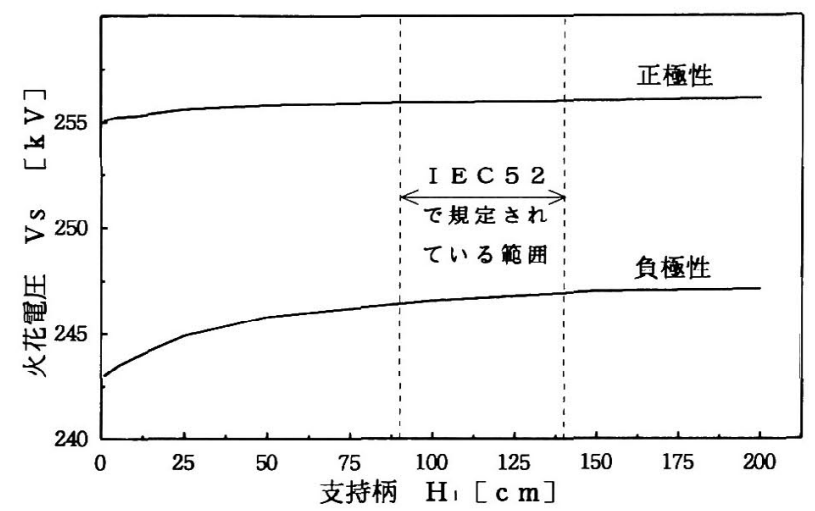

図 2 火花電圧に対する支持柄の影響 $\left(\mathrm{H}_{2}=25 \mathrm{~cm}, \mathrm{~L}=5 \mathrm{~cm}\right)$

Fig.2. Influence of the length of surpporting shank.

同様に, 高圧側柄 $\mathrm{H}_{2}$, 柄の太さ $\mathrm{L}$ 変えて火花電圧を 計算した。これらの結果を図 2 を含め, まとめて表 2 に示 す。なお、すべての場合に, 負極性の方が火花電圧の変化 がやや大きいので、表 2 は負極性の場合のみを示した。

表 2 柄の長さと太さが負極性火花電圧に与える影響 (球直径 $25 \mathrm{c} \mathrm{m}$, ギャップ長 $10 \mathrm{~cm}$ )

Table 2. Influence of the length and the diameter of the shanks for negative disruptive discharges.

\begin{tabular}{|c|c|c|c|}
\hline $\begin{array}{l}\text { 要 } \\
\text { 因 }\end{array}$ & $\begin{array}{l}\text { I E C } 52 \text { に規定 } \\
\text { されている範囲 }\end{array}$ & $\begin{array}{l}\text { 規定範囲における } \\
\text { 火花電压の変化 }\end{array}$ & $\begin{array}{l}\text { 火花電压の最大値 } \\
\text { と最小值の差 }\end{array}$ \\
\hline $\mathrm{H}_{1}$ & $90 \sim 140 \mathrm{~cm}$ & $246.48 \sim 246.94 \mathrm{kV}$ & $0.19 \%$ \\
\hline $\mathrm{H}_{2}$ & $25 \sim(100 \mathrm{~cm})$ & $246.60 \sim 247.29 \mathrm{kV}$ & $0.28 \%$ \\
\hline L & $(2.5) \sim 5 \mathrm{~cm}$ & $246.53 \sim 246.60 \mathrm{kV}$ & $0.03 \%$ \\
\hline
\end{tabular}

( $\mathrm{H}_{1}=100 \mathrm{c} \mathrm{m}, \mathrm{H}_{2}=25 \mathrm{~cm}, \mathrm{~L}=5 \mathrm{~cm}$ を基準と し,このうち 1 つを変化)

なお, I E C 52 では, 表 2 の $\mathrm{H}_{2}$ の上限, Lの下限を規 定していない。ここでは $\mathrm{H}_{2}=100 \mathrm{~cm}$ 参考までに上 限とし，Lでは我国のJＩＳＣ１００１が規定している 下限を用いた。

\section{5.おわりに}

標準球ギャップのインパルス電圧に対する火花電圧に, 電界を通じて影響を与える要因のうち, 柄の長さと太さに ついて, 電離指数計算を用いて火花電圧の検討をした。球 直径 $25 \mathrm{~cm}$ ，ギャップ長 $10 \mathrm{~cm}$ の比較は影響が大きい と考えられる側の結果であるが，これらの要因の影響は極 めて小さいという結果が得られた。

今後は壁などの近接物体の影響を検討し, 総合的に評価
する事が必要と考えられる。

(平成 9 年 2 月 25 日受付) 文 献

[ 1 ]A.Pedersen: "Calculation of Spark Breakdown or Corona Starting Voltages in Nonuniform Fields", IEEE Trans.,PAS-86,pp.200 206(1967)

[ 2 ]A.Pedersen: "Analysis of Spark Breakdown Characteristics for Sphere Gaps",IEEE Trans., PAS-86,pp.975 978(1967)

[ 3 ]A.Pedersen: "Criteria for Spark Breakdown in Sulfur Hexafluoride", IEEE Trans.,PAS-89, pp.2043 2048(1970)

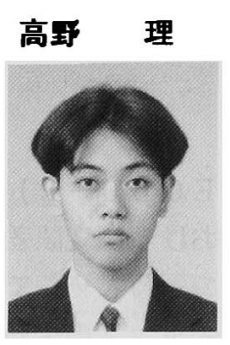

（学生員）1972年 2 月17日生まれ。1995 年 3 月工学院大学電気工学科卒業。同年 4 月同大学大学院工学研究科進学, 現在 に至る。1997年電気学会論文発表賞受賞。

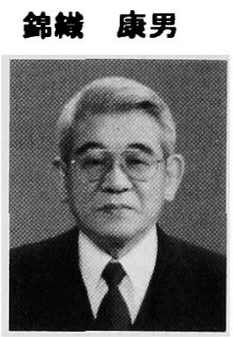

（正員）1941年11月14日生まれ。1968年 3 月土学院大学大学院工学研究科修士課 程修了。同年 4 月より工学院大学工学部 電気工学科に勤務。電子顕微鏡の研究を 経て, 現在高電圧放電現象の研究に従事, 電気工学科講師。日本電顕, 応用物理, 静電気学会各会員。

村里 （正員）1930年3月23日生まれ。1953年3

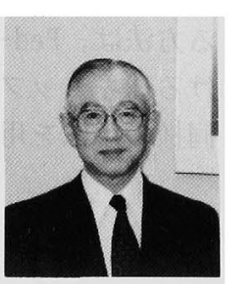
月慶応義塾大学大学院電気工学専攻修了。 1953年 4 月東京芝浦電気 K K 鶴見研究所 に勤務。1975年工学博士。東芝重電副技 師長, 東芝重電技術研究所次長等を歷任。 1985 年 3 月東芝退社。同年 4 月より工学院 大学教授, 現在に至る。電力工学担当。 日本電機工業会より表彰される。

河里 照哉（正員）1934年6月21日生まれ。1962年3 月東京大学大学院数物系研究科修了, 工 学博士。1962年 4 月より東大工学部電気 工学科に勤務。1995年 3 月東大を定年退 職。同年 4 月より工学院大学教授, 現在 に至る。高電圧工学担当。電気学会より 論文賞, 著作賞, 電力賞を受賞。1980, 1981年度電気学会編修理事。1988年東京 支部長，1991年度 A 部門長。 